\title{
Extent of Women's Participation in Silk Industry in Imphal West District of Manipur, India
}

\author{
W. Miranda*, M. Deepa Devi, Daya Ram and S. Kareini Kayina
}

Department of Extension Education, College Of Agriculture, Central Agricultural University, Imphal-795004, Manipur (India)

*Corresponding author

\section{A B S T R A C T}

\section{Keywords}

Silk industry, Active participation,

Moderate

participation, Passive participation

\section{Article Info}

Accepted:

15 June 2018

Available Online:

10 Julv 2018
The present study was conducted during the year 2017-18 in Imphal West, Manipur. A total of 150 women respondents were selected through snowball sampling method. The selected respondents were interviewed personally using pre tested well-structured interview schedule. The data collected from the 150 women respondents revealed that majority of the respondents $(58.00 \%)$ had medium participation in silk industry followed by low participation $(31.33 \%)$ and high participation $(20.67 \%)$. \%). Correlation analysis between the extent of women's participation in silk industry and the independent variables revealed that out of seven independent variables, education, land holding, social participation and training exposure were found to be positively significant at 0.05 level of probability, family size was found to be negatively significant at 0.05 level of probability and there was no significant relation between the extent of women's participation in silk industry with age and decision making of the respondents.

\section{Introduction}

Women are the backbone for development of rural and national economies. Gender division of labour varies from one society and culture to another and within each culture external circumstances influence the level of activity (Nigest, 2004). They account for more than half of the agricultural work force by participating in different activities either directly or indirectly. They comprise 43 per cent of the world's agricultural labour force. Women of course form an integral part of the farming household. They bear most of the responsibilities for households, food security and contribute to household well being through their income generating activities (Etenesh, 2005).

Women usually have limited access to resources and opportunity and their productivity remains low relative to their potential. They are not always aware of the improvements they could make by using scientific and technological knowledge. Thus, the attention of farm women were directed towards the women friendly improved tools. According to Lynda (1991), women's role has not been recognized due to lack of awareness in our society. Farm women from the 
unorganized sector are vulnerable as new and improved technologies are inaccessible to them. It is imperative that they are exposed to these technologies and encouraged and motivated to adopt the new technologies which would help them to improve their quality of life.

Sericulture is the cultivation of silk through rearing of silkworm. It involves the rearing of food plants for silkworm, rearing of silkworm for production of cocoons, reeling and spinning of cocoon for production of yarn, etc. for value added benefits such as processing and weaving. Kasi (2013) rightly opined, "Sericulture is a labour-intensive agro-based activity and is also an industry". Sericulture is of great importance in many countries in providing gainful employment, economic development and improvement in the quality of life of rural people. It suit both marginal and small-scale land holders because of its low investment, high assured returns, short gestation period, rich opportunities for enhancement of income and creation of family employment round the year. It also plays a major role in anti-poverty programme and prevents migration of rural people to urban areas in search of employment. Keeping these views in mind, the present study was undertaken to investigate Extent of Women's Participation in Silk Industry in Imphal West District of Manipur.

\section{Materials and Methods}

The present study was conducted during the year 2017-2018 in Imphal West of Manipur. There are 16 Districts of Manipur. Imphal West District was selected for present study. There are four blocks of this district; one block was selected purposively for the present study as the work of silk industry is confined to Lamshang block only. There are 56 villages in the Lamshang Block. Khurkhul and Phayeng village were purposively selected for the present study. A sample size of 150 respondents was drawn for the study through snowball sampling. Three components of extent of women participation in silk industry namely participation in cocoon production, participation in silk production and participation in marketing activities were analyzed. For each component, three types of participation were assigned viz. active participation, moderate participation and passive participation. Scoring was given for each participation in such a way that 3 score was given for active participation, 2 score for moderate participation and 1 score for passive participation. The primary data was collected using pre-tested structured interview schedule. Analysis of primary data was carried out using multidimensional scaling technique of SPSS16 besides conventional correlation analysis as part of exploratory approach of data analysis.

\section{Results and Discussion}

The extent of women's participation in silk industry was taken as the sum of the scores obtained by the respondents from various components viz. participation in cocoon production, participation in silk production and participation in marketing activities. The total score obtained by each respondent was converted to percent score to bring it to a uniform base and these were treated as final scores for further analysis and interpretation.

\section{Participation in cocoon production}

It is evident from Table 1 that the highest percentage of the respondents $(38.00 \%)$ falls under the category of passive participation in cocoon production followed by 32.67 per cent under moderate participation and 29.33 per cent under active participation. This might be due to lack of motivation to participate in cocoon production. The participation of women is less in cocoon production as they lack adequate knowledge and skill for rearing of silkworms. 


\section{Participation in silk production}

Table 1 affirmed that majority per cent of the respondents were found under moderate participation and same percentage of women (29.33\% each) was found under active and passive participation. The possible reason would be that the women in the study area have adequate knowledge and skill for silk production. They tend to participate more in silk production as a cultural and traditional way of living.

\section{Participation in marketing activities}

The women respondents differ from one another in their contribution to marketing activities. According to their differences in contribution to marketing, three areas of participation in marketing activities were analyzed.

\section{Participation in cocoon marketing}

It was found that out of 29 cocoons selling respondents, 75.87 per cent had moderate participation in marketing of cocoon, followed by 13.79 per cent having passive participation and 10.34 per cent having active participation. This might be due to moderate cocoon production by the respondents in a year and fluctuations in cocoon yield.

Table.1 Extent of women's participation in Silk Industry

\begin{tabular}{|c|c|c|c|c|}
\hline $\begin{array}{l}\text { Sl. } \\
\text { No. }\end{array}$ & $\begin{array}{l}\text { Extent of women } \\
\text { participation in silk } \\
\text { industry }\end{array}$ & $\begin{array}{l}\text { Classification of } \\
\text { Category }\end{array}$ & Frequency & Percentage \\
\hline A. & \multicolumn{4}{|c|}{ Participation in cocoon production } \\
\hline \multirow[t]{3}{*}{ a. } & \multirow{3}{*}{$\begin{array}{l}\text { Participation in cocoon } \\
\text { production }\end{array}$} & Active participation & 44 & 29.33 \\
\hline & & Moderate participation & 49 & 32.67 \\
\hline & & Passive participation & 57 & 38.00 \\
\hline B. & \multicolumn{4}{|c|}{ Participation in silk production } \\
\hline \multirow{3}{*}{ a. } & \multirow{3}{*}{$\begin{array}{l}\text { Participation in silk } \\
\text { production }\end{array}$} & Active participation & 44 & 29.33 \\
\hline & & Moderate participation & 62 & 41.34 \\
\hline & & Passive participation & 44 & 29.33 \\
\hline C. & \multicolumn{4}{|c|}{ Participation in marketing activities } \\
\hline \multirow[t]{3}{*}{ a. } & \multirow{3}{*}{$\begin{array}{l}\text { Participation in cocoon } \\
\text { marketing }\end{array}$} & Active participation & 3 & 10.34 \\
\hline & & Moderate participation & 22 & 75.87 \\
\hline & & Passive participation & 4 & 13.79 \\
\hline \multirow[t]{3}{*}{ b. } & \multirow{3}{*}{$\begin{array}{l}\text { Participation in silk } \\
\text { marketing }\end{array}$} & Active participation & 8 & 22.86 \\
\hline & & Moderate participation & 25 & 71.42 \\
\hline & & Passive participation & 2 & 05.72 \\
\hline \multirow[t]{3}{*}{ c. } & \multirow{3}{*}{$\begin{array}{l}\text { Participation in silk } \\
\text { garments marketing }\end{array}$} & Active participation & 23 & 26.74 \\
\hline & & Moderate participation & 45 & 52.33 \\
\hline & & Passive participation & 18 & 20.93 \\
\hline
\end{tabular}


Table.2 Distribution of Overall participation in silk industry

\begin{tabular}{|l|c|c|c|}
\hline \multicolumn{2}{|c|}{} & \multicolumn{2}{c|}{$\mathrm{N}=150$} \\
\hline Sl.No. & Category & Frequency & Percentage \\
\hline 1. & Low & 32 & 21.33 \\
\hline 2. & Medium & 87 & 58.00 \\
\hline 3. & High & 31 & 20.67 \\
\hline Total & & $\mathbf{1 5 0}$ & $\mathbf{1 0 0}$ \\
\hline
\end{tabular}

Table.3 Relationship between personal, socio-economic and psychological characteristics of women participation in silk industry

\begin{tabular}{|l|l|c|}
\hline \multicolumn{1}{|c|}{ Sl.No. } & \multicolumn{1}{c|}{ Characteristics } & Correlation coefficient (r) \\
\hline $\mathbf{X}_{\mathbf{1}}$ & Age & $-0.234(\mathrm{NS})$ \\
\hline $\mathbf{X}_{\mathbf{2}}$ & Education & $0.825^{*}$ \\
\hline $\mathbf{X}_{\mathbf{3}}$ & Family size & $-0.664^{*}$ \\
\hline $\mathbf{X}_{\mathbf{4}}$ & Land holding & $0.777^{*}$ \\
\hline $\mathbf{X}_{\mathbf{5}}$ & Decision making ability & $0.069(\mathrm{NS})$ \\
\hline $\mathbf{X}_{\mathbf{6}}$ & Social participation & $0.861^{*}$ \\
\hline $\mathbf{X}_{\mathbf{7}}$ & Training exposure & $0.817^{*}$ \\
\hline
\end{tabular}

\section{Participation in silk marketing}

It was found that out of 35 silk selling respondents, 72.42 per cent had moderate participation in silk marketing, followed by 22.86 per cent active participation and 5.71 per cent passive participation.

This possible reason would be that the women in the study area produce silk at a moderate rate in a year. Hence, there is more of moderate participation in silk marketing.

\section{Participation in silk garments marketing}

The women participating in marketing of silk garments were grouped into three categories of participation based on the number of garments sold per year. In Table 1, it was found that 52.32 per cent of the respondents were moderately involved in marketing of silk garments, followed by 26.74 per cent involving actively and 20.93 per cent involving passively.
Overall participation of women in silk industry

The participation of women in silk industry was placed under three categories as shown in Table 2 majority of the respondents $(58.00 \%)$ had medium participation, followed by 21.33 per cent had low participation in silk industry and 20.67 per cent had high level of participation. The possible reasons for medium participation in silk industry may be due to medium contribution of women in silk production and marketing activities.

It is evident from the values of correlation coefficient presented in Table 3 that the variables education, land holding, social participation and training exposure were found to be positively correlated with the extent of women's participation in silk industry at 0.05 level of probability and that of family size was negatively correlated with the extent of women's participation in silk industry at 0.05 level of probability. 
It could be concluded that majority $(58.00 \%)$ of the women in Imphal West District of Manipur had medium participation, followed by 21.33 per cent had low participation in silk industry and 20.67 per cent had high level of participation. Education, land holding, social participation and training exposure of the respondent was found to be positively correlated with their participation in silk industry while family size was found to be negatively correlated with their participation in silk industry. With proper training and finance facilities, participation of the women in silk industry can be enhanced.

\section{Acknowledgement}

The authors acknowledge the contributions of Wangkhem Miranda, M. Deepa Devi, Daya Ram and S. Kareini Kayina, Department of Extension Education, College Of Agriculture, Central Agricultural University, Imphal, Manipur (India) for their technical support and valuable contributions to the manuscript.

\section{References}

Anitha, R. and Kanimozhi, V. (2013). Women entrepreneurs in sericulture: their participation and problems faced. Asia pacific J. Res., 1(7).

Chowdhury, S.R., Umasankar, Das, N.K., Sahu, P.K. and Majumder, M.K. (2011). Studies on involvement of women and their contribution share in sericulture activities. J. Crop and Weed, 7(2): 37-40.

David, R., Sarkar, J.D., Shrivastav, K.K. and Sharma, M.L. (2008). Socio-personal and socio-psychological characteristics of the trained farm women. J. Soil. Crop., 18(2): 333-337.

Etenesh, B. (2005). Handout for Gender Issues and Youth work in Agricultural Extension, Almery

Goswami, C. and Bhattacharya, M. (2013). Contribution of Sericulture to Women's Income in Assam: A Case Study in Goalpara District of Assam, India. Int. J. Sci. and Res., 3(3).

Kasi, E. (2013). Role of Women in Sericulture and Community Development: An Article on a Study from a South Indian Village. Sage open, 1-11.

Lynda, (1991). Gender inequality (Kasente cited in Tackle, 2008).

Nigest, S. (2004). Gender Main streamlining world vision.

Prameelamma, V. (1990). A study on knowledge and participation of rural women in agriculture operations with respect of paddy crop in Kurnool district of Andhra Pradesh. Unpublished M.Sc. (Agri.) Thesis. University of Agricultural Sciences, Bangalore.

\section{How to cite this article:}

Miranda, W., M. Deepa Devi, Daya Ram and Kareini Kayina, S. 2018. Extent of Women's Participation in Silk Industry in Imphal West District of Manipur, India. Int.J.Curr.Microbiol.App.Sci. 7(07): 1838-1842. doi: https://doi.org/10.20546/ijcmas.2018.707.218 